\title{
A Review of Circular Economy Prospects for Stainless Steelmaking Slags
}

\author{
Lauri Holappa $^{1}$ (i) $\cdot$ Marko Kekkonen $^{1} \cdot$ Ari Jokilaakso $^{1} \cdot$ Juha Koskinen $^{2}$
}

Received: 9 April 2021 / Accepted: 10 June 2021 / Published online: 28 June 2021

(c) The Author(s) 2021

\section{Abstract}

The world of stainless steel production was $52 \mathrm{Mt}$ in 2019, and the annual amount of slags including electric furnace, AOD converter, ladle, and casting tundish, was estimated at 15-17 Mt. Nowadays, only a minor fraction of slags from stainless steel production is utilized and a major part goes to landfilling. These slags contain high-value elements (Cr, Ni, Mo, Ti, V...) as oxides or in metallic form, some of them being environmentally problematic if dumped. Thus, any approach toward circular economy solutions for stainless steel slags would have great economic and environmental impacts. This contribution examines the slags from different process stages, and the available and new potential means to increase internal recycling and to modify slags composition and structure by optimizing their properties for reclaiming in high-value applications. Eventual methods are, e.g., fast controlled cooling and modifying additives. Means to recover valuable metals are discussed as well as potential product applications to utilize various slags with different chemical, physical, and mechanical properties. By integrating the treatments and steering of slags' properties to the total process optimization system, the principles of circular economy could be achieved.

The contributing editor for this article was Mansoor Barati.

Lauri Holappa

lauri.holappa@aalto.fi

1 Department of Chemical and Metallurgical Engineering, School of Chemical Engineering, Aalto University, 02150 Espoo, Finland

2 Tapojärvi Oy, 95400 Tornio, Finland 


\section{Graphical Abstract}

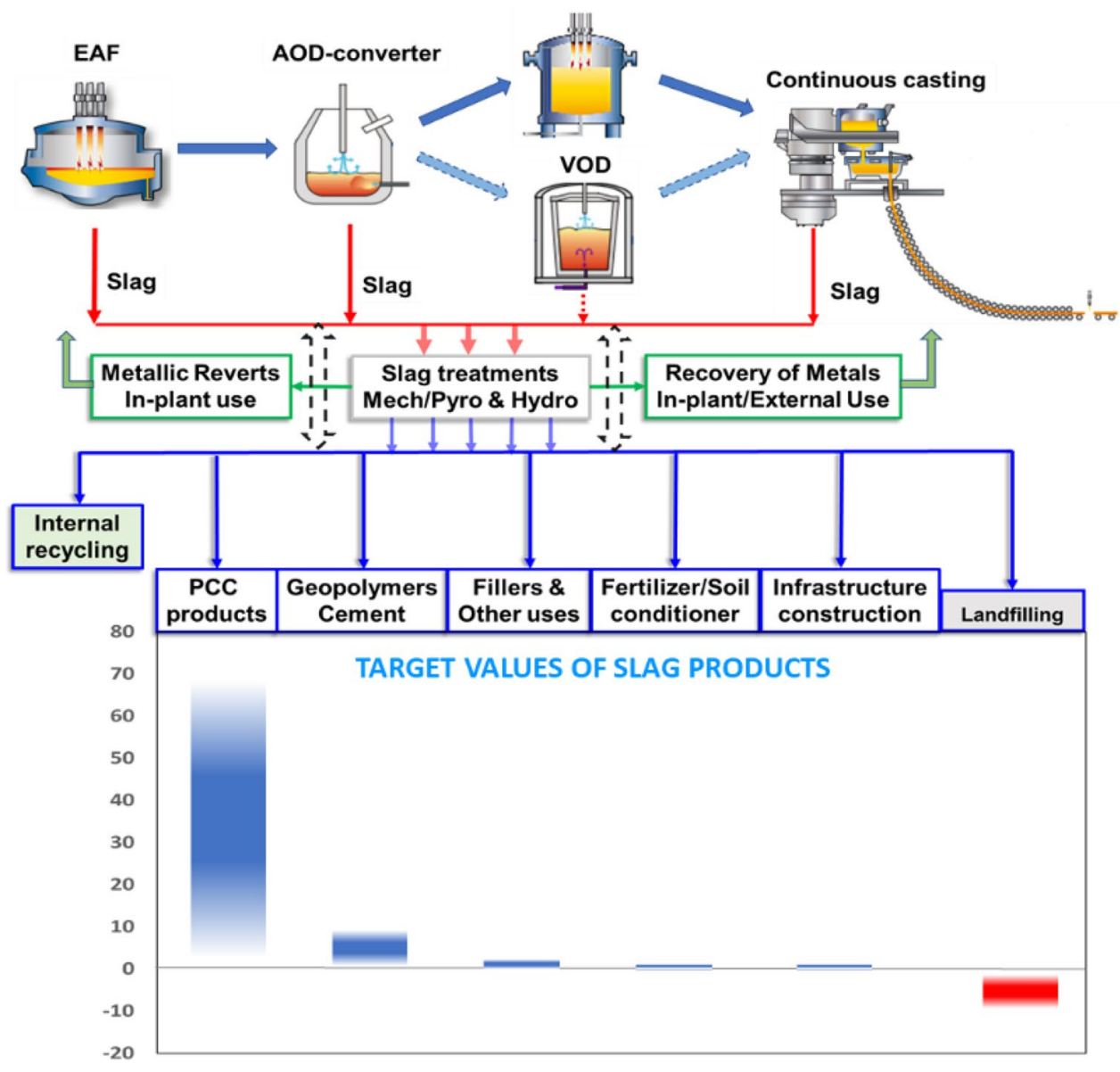

Keywords Slags utilization $\cdot$ Metals recovery $\cdot$ Recycling $\cdot$ Slags properties $\cdot$ Productization $\cdot$ Environmental issues

\section{Introduction}

Stainless steel is the most rapidly growing metal with an annual growth rate of 5.33\% (1980-2019) [1]. That number matches well with Fig. 1 which shows the recent progress from the year 2005: the production has doubled in 15 years and approached $52 \mathrm{Mt}$ in 2019 belonging to the same category with aluminum and copper as to the volume and value. The overall world steel production was 1869 $\mathrm{Mt} / 2019$ [2]. The iron and steel production together generated a massive quantity of slags $(\approx 600 \mathrm{Mt} /$ year$)$. Such volumes cannot be landfilled for environmental and economic reasons, and various treatments and applications have been intensively developed. Nowadays, a high percentage is either recycled, reused, or valorized in different applications. The total amount of slags from stainless steel production was estimated as 15-17 Mt/year including slags from different process stages, EAF melting, AOD \& VOD converting, ladle operations, and casting [3]. The present situation of slags from stainless steel production is different: on average, only a minor fraction is utilized, and a major part goes to landfilling. The utilization degree varies from zero to $100 \%$ depending on the plant's course of action. An apparent reason is that stainless steel plants are small compared to carbon steel plants, and the amount of slags are minor, respectively. Hence, landfilling has been a simple means and permitted thus far, but problems may arise in the long run. Another reason is the complexity of these slags, which makes the treatment and utilization more demanding. It also needs investments in equipment. Consequently, the slag processing has not been considered economically attractive enough, and many steel plants have settled down to steel production and marginalized secondary functions. But there are several positive grounds as well which are highlighted through this article.

Differing from blast furnace and converter slags, stainless steelmaking slags contain high-value elements $(\mathrm{Cr}, \mathrm{Ni}, \mathrm{Mo}$, $\mathrm{Ti}, \mathrm{V})$ as oxides or in metallic form. An efficient recovery 


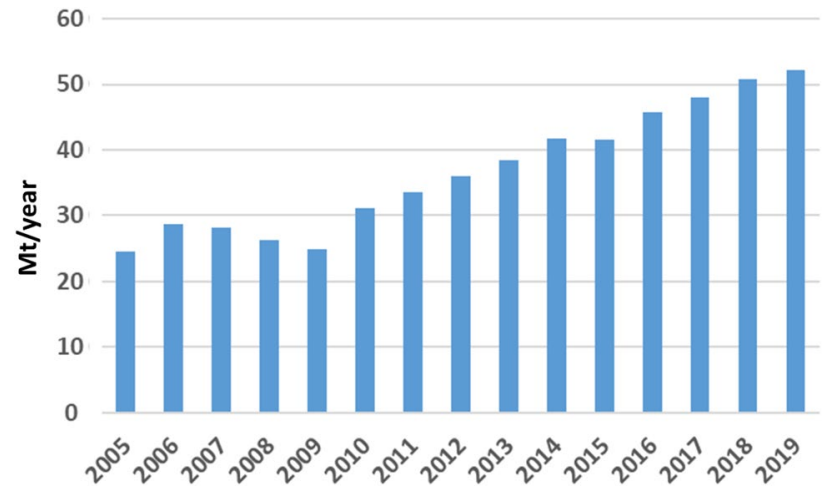

Fig. 1 The growth of world stainless steel production in the years 2005-2019 [1]

of these metals is an economic driver and an environmental target for saving the use of natural resources. Another environmental aspect is that some components in slags can be environmentally problematic if dumped. $\mathrm{Cr}(\mathrm{VI})$ is a wellknown risk, and its formation should be eliminated. $\mathrm{Cr}$ and $\mathrm{Ni}$ are also carcinogens $[4,5]$. Fluorspar $\left(\mathrm{CaF}_{2}\right)$ is commonly used as flux in stainless steel slags causing an environmental risk. Dusting is a further problem characteristic to slags with high basicity. To summarize the foregoing aspects, all actions towards circular economy solutions will have a great economic and environmental potential. The aim of this contribution is to review available and new feasible means to increase internal recycling, and to modify slags composition and structure as objectives to optimize their properties for reclaiming in different high-value applications. Eventual methods are, e.g., modifying additives and fast controlled cooling. Different means to maximize the recovery of valuable metals are reviewed as well as potential product applications to utilize various slags.

\section{Slags from Different Unit Processes}

An overall scheme of stainless steelmaking is shown in Fig. 2. The process starts with melting stainless scrap, ordinary recycled steel charging, and alloying additions $(\mathrm{FeCr}$, $\mathrm{FeMo}, \mathrm{FeNi}$ ) in an electric arc furnace (EAF). The aim is to prepare a liquid steel charge close to the final composition as for the main alloying elements and proper carbon and silicon contents for the subsequent AOD (Argon Oxygen Decarburization) or alternatively VOD (Vacuum Oxygen Decarburization) converter. Melting with arcs assisted by oxygen blowing results in a partial oxidation of $[\mathrm{C}]$ and most of [ $\mathrm{Si}$ ] to final contents about $1-1.5 \% \mathrm{C}$ and $0.1-0.2 \% \mathrm{Si}$. The $\mathrm{Cr}$ oxidation is strived to restrict and to avoid too high $\mathrm{Cr}_{2} \mathrm{O}_{3}$ content in the slag via these residual contents, especially [\% Si]. In the case of direct VOD treatment (without AOD process), lower $[\mathrm{C}]$ is required after the EAF.

In the AOD converter, carbon is oxidized to low contents $(\leq 0.05 \%)$ by $\mathrm{O}_{2}+\operatorname{Ar}\left(\mathrm{N}_{2}\right)$ blowing starting with $100 \% \mathrm{O}_{2}$ and by stepwise lowering $\mathrm{p}_{\mathrm{O} 2}$ from $100 \%$ to zero and increasing $\mathrm{p}_{\mathrm{Ar}}$ from zero to $100 \%$, in tandem. Carbon oxidation is preferred to $\mathrm{Cr}$ oxidation when $\mathrm{p}_{\mathrm{CO}}$ is decreased by neutral gas $\left(\mathrm{Ar}, \mathrm{N}_{2}\right)$ dilution. In VOD converter, $\mathrm{p}_{\mathrm{CO}}$ is reduced by

Fig. 2 The scheme of different unit processes in stainless steelmaking and formation of slags

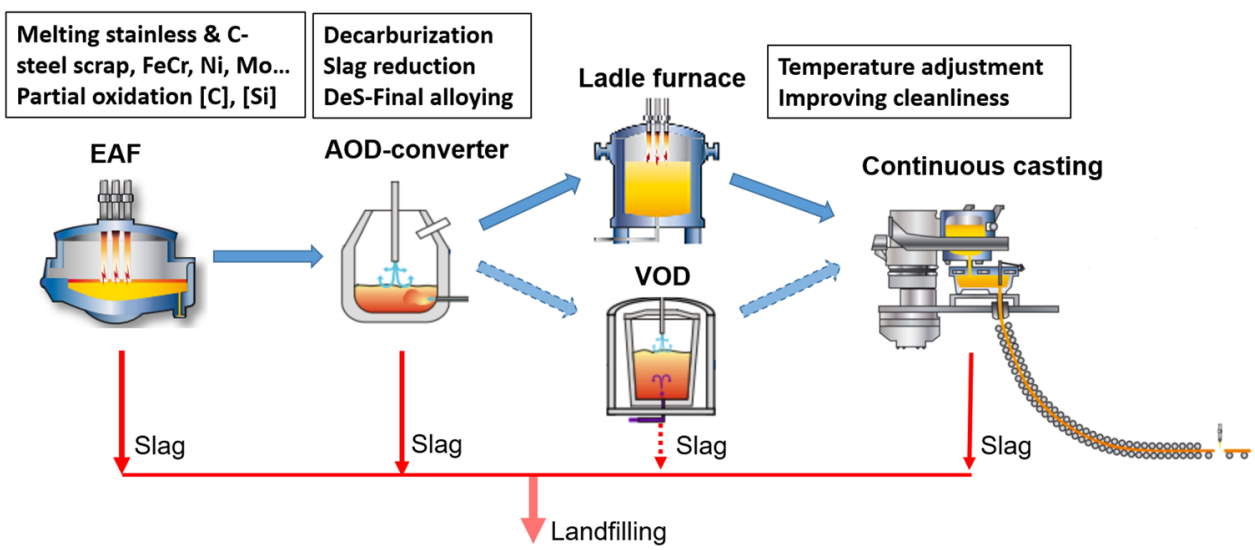

Table 1 Approximate compositions and amounts of slags from stainless steelmaking

\begin{tabular}{llllllllll}
\hline Unit process & $\mathrm{CaO}$ & $\mathrm{SiO}_{2}$ & $\mathrm{MgO}$ & $\mathrm{Al}_{2} \mathrm{O}_{3}$ & $\mathrm{Cr}_{2} \mathrm{O}_{3}$ & $\mathrm{CaO} / \mathrm{SiO}_{2}$ & $\mathrm{CaO}+\mathrm{MgO} / \mathrm{SiO}_{2}$ & Amount kg/t steel & Minor other components \\
\hline EAF & $40-45$ & $25-30$ & $5-12$ & $5-10$ & $3-7$ & $1.5-1.8$ & $1.7-2.0$ & $100-150$ & $\mathrm{Fe}, \mathrm{Mn}, \mathrm{Ti}, \mathrm{V}, \mathrm{Ni}$ \\
AOD & 55 & $25-30$ & $5-10$ & $1-5^{\mathrm{a}}$ & $0.5-1$ & 2 & 2.5 & $100-120$ & $\mathrm{CaF}_{2}$ \\
LF-CC & $55-60$ & $20-30$ & $5-10$ & $1-5^{\mathrm{a}}$ & $1-5$ & $2-3$ & $2.2-3$ & $15-20$ & $\mathrm{CaF}_{2}, \mathrm{Ti}, \mathrm{Nb}, \mathrm{V} \ldots$ \\
\hline
\end{tabular}

${ }^{a}$ Even higher when the slag is reduced, and steel deoxidized with $\mathrm{Al}$ - or Ca-aluminate added into the slag 
low pressure, i.e., vacuum. Anyway, towards very low [C], some $[\mathrm{Cr}]$ is oxidized, and quite high $\mathrm{Cr}_{2} \mathrm{O}_{3}$ contents about $25 \%$ can be found in AOD slag after the decarburization period. Therefore, the next necessary stage is slag reduction done by adding $\mathrm{FeSi}$ or eventually $\mathrm{Al}$ into the steel melt and stirring with argon gas. After the slag reduction stage, the $\mathrm{Cr}$ content in the slag is aimed at low contents e.g., $0.5 \% \mathrm{Cr}_{2} \mathrm{O}_{3}$. Then the slag is tapped to a slag pot, and lime and fluorspar are added into the converter to form basic liquid slag for a short desulfurization treatment with intensive Ar stirring. In addition to the composition of AOD slag in Table 1, the slag after reduction can contain several percent fluorspar.

After tapping into the ladle, $\mathrm{CaO}$ and $\mathrm{CaF}_{2}$ are added again to form a basic slag to protect the steel from the influence of air, to absorb deoxidation products from the steel, and to improve steel cleanliness via ladle metallurgical (LM) treatments under Ar stirring. Trimming alloying is performed as well. It is common that the LM treatments take place in a ladle furnace (LF) which makes temperature adjustment easy. The LF slag follows on the ladle to continuous casting (CC), and after the cast end, the slag is poured into a slag pot. An adjunct slag used in the CC tundish is typically more acidic. Its function is thermal insulation and protecting steel during casting. The amount is minor and was not presented separately in Table 1. It can be incorporated in other slags. As a general comment, $\mathrm{MgO}$ (dolomitic lime) is added into slags to protect magnesia-based refractory linings. It influences the properties of the slag, e.g., basicity, Cr solubility, melting temperature, and viscosity as well as the mineralogical structure after solidification and cooling.

In Table 1, the main three types of slags are described. The figures are approximate composition ranges based on Nordic steel plants. They refer to slag compositions in situ at the end of each process stage and do not include eventual large metal lumps. Of course, slags are factory specific and can differ substantially due to various raw materials, process operation, and steel grades to be produced. In Table 1, the slags from different unit processes differ both in basicity, $\mathrm{Cr}$ content, and minor impurities. Except for the oxide forming components in the slag, also less-oxidizable metals like $\mathrm{Ni}$ and Mo can be found but mostly in metallic particles ejected from the bulk steel or endogenously formed inside the slag via the reduction process. In addition, slags can retain macroscopic metal particles, splashes, skulls, tapping remains, etc., which are not included in the slags' compositions above. Their removal and recovery in an early stage of a treatment process is essential. Nowadays, a typical slag processing route in a stainless steel plant consists of wet grinding and metal separation. It is emphasizing metal recovery but has quite restricted ability to slag recycling and productization. Depending on slag composition, cooling method (slag pit vs. intensified water cooling), and grinding, the basic slag material is delivered to purposes such as road and infrastructure construction. Unfortunately, most slags from stainless steelmaking still go to landfilling which needs space, causes loss of valuable resources, and is hazardous to human health and the environment. As mentioned earlier, the main risk is the eventually high $\mathrm{Cr}$ content which can lead in contamination of soil and water in the form of leachable $\mathrm{Cr}$ (VI). $\mathrm{Cr}$ and $\mathrm{Ni}$ are also carcinogens. Avoiding negative impacts is a strong motivation for emphasized slags utilization, but there is also a great economic potential via improved recovery and slags valorization. In the following chapters feasible treatments for improved metals, recovery and valorized utilization of slags are surveyed. Both established methods and new innovative solutions are discussed. In many cases, the references are from carbon steel production, whereupon the special features of slags from stainless steel making should be considered when contemplating potential applications.

\section{Metals Losses in Slags}

Metals as dispersed fine particles or dissolved as oxides in slags are difficult to recover. Let us consider our primary interest, $\mathrm{Cr}$ as an example to examine which factors influence its presence in the slag. The content of oxidized $\mathrm{Cr}$ " $\mathrm{Cr}_{2} \mathrm{O}_{3}$ " in the end slag of the EAF process or the slag from the AOD reduction stage depends on the oxygen potential (defined as $\mathrm{p}_{\mathrm{O} 2}$ or $\mathrm{a}_{[\mathrm{O}]}$ ), which is determined by the ambient contents (activities) of [Cr] and the controlling solutes [Si] and eventually $[\mathrm{C}]$ in the EAF. Hitherto, the ambient temperature as well as the slag and liquid metal compositions influence via the activity of $\mathrm{Cr}_{2} \mathrm{O}_{3}$ and $\mathrm{a}_{[\mathrm{Cr}]}$, respectively. Thermodynamic and kinetic aspects were investigated and discussed, e.g., by M. Guo et al. [6, 7]. The equilibrium $\mathrm{Cr}$ distribution between the slag and steel $(\% \mathrm{Cr})_{\text {slag }} /[\% \mathrm{Cr}]_{\text {steel }}$ can be derived from the reaction equation:

$2[\mathrm{Cr}]+3[\mathrm{O}] \leftrightarrow\left(\mathrm{Cr}_{2} \mathrm{O}_{3}\right)$,

$K_{1}=\frac{a_{\mathrm{Cr}_{2} \mathrm{O}_{3}}}{a_{\mathrm{Cr}}^{2} \cdot a_{\mathrm{O}}^{3}}$.

Chromium oxide was simplified here as 3-valent oxide $\mathrm{Cr}_{2} \mathrm{O}_{3}$, although it is well known that in low $\mathrm{p}_{\mathrm{O} 2}$ conditions, also 2-valent oxide $\mathrm{CrO}$ exists [8,9]. In a process with oxygen blowing, $\mathrm{p}_{\mathrm{O} 2}$ or $\mathrm{a}_{[\mathrm{O}]}$ is controlled by carbon oxidation reaction, $\mathrm{a}_{[\mathrm{O}]}$ increases, and the equilibrium is approached from left to right. The ambient top slag can become even supersaturated with oxygen via $\mathrm{Cr}$ oxides, especially when $\mathrm{O}_{2}$ top blowing is applied. In a reduction stage, $\mathrm{a}_{[\mathrm{O}]}$ is controlled and pressed down by adding silicon or aluminum, and 
the reaction should go backwards. The gross reactions can be written as follows:

$\left(\mathrm{Cr}_{2} \mathrm{O}_{3}\right)+3 / 2[\mathrm{Si}]=2[\mathrm{Cr}]+3 / 2\left(\mathrm{SiO}_{2}\right)$,

$\left(\mathrm{Cr}_{2} \mathrm{O}_{3}\right)+2[\mathrm{Al}]=2[\mathrm{Cr}]+\left(\mathrm{Al}_{2} \mathrm{O}_{3}\right)$

According to several researchers, a primary reduction mechanism is the reaction between the metal bath and the emulsified slag droplets due to the large surface area of the droplets as well as efficient mass transfer due to the intensive stirring conditions in a side-blown converter [10-12]. When the reaction takes place at the slag/metal interface, the formed metal can easily merge into the bulk metal. However, when reduction occurs inside the slag-metal emulsion, the formed metal can end up in the bulk slag and remain there as fine droplets or precipitates. Then the settling rate depends on several factors like the droplet size, slag's viscosity, as well as the density difference and interfacial tension between slag and metal. In an AOD converter, the slag composition, its properties, and the process parameters, like temperature and gas flow rate, are relatively well controlled, and consequently, the reduction rate and the final reduction degree can be reasonably predicted [12]. The situation in the EAF smelting is different. As seen in Table 1, the $\mathrm{Cr}_{2} \mathrm{O}_{3}$ content is much higher in the EAF slag than in the AOD reduction slag. Also, the scatter can be quite high (up to 10-15\% $\mathrm{Cr}_{2} \mathrm{O}_{3}$ [6]), and the control of final $\mathrm{Cr}_{2} \mathrm{O}_{3}$ is difficult due to the complexity of the process with varying raw materials and melting efficiency, injected additions, slag's behavior (eventual foaming), and more or less contradictory targets when trying to reconcile the final $[\mathrm{C}]$ and $[\mathrm{Si}]$ contents on the one hand and metals losses into the slag $(\mathrm{Cr}, \mathrm{Mn}, \mathrm{Mo}$, $\mathrm{Ni}$...) on the other. When optimizing the operation of the total EAF-AOD integrate, metallurgical and productivity aspects are of primary concern. In addition, maximizing metals recovery and minimizing losses and steering of slags properties for subsequent treatments and final applications should be inevitable issues as well.

\section{Metals Separation and Recovery: Pyro- and Hydrometallurgical Treatments}

Metals recovery from slags can be done via physical and chemical means. Physical separation is applicable for large metallic particles; the slag should be first properly comminuted to liberate the metals after which metal is removed by gravimetric and/or magnetic methods [13-16]. EAF slags have the best potential in good metal recovery due to the highest metal content. Conventionally, slags are merged for treatments, but it would be possible to handle each slag type independently, even by considering slags from production of different steel grades (e.g., Ni, Mo, Ti, V). Then each slag type could get its own specific post-treatment without getting blended into the big bulk. The recovered metals can be recycled as reverts to process. The quantity is typically several percent of the slag weight. In the case of stainless steel, the value of $\mathrm{Cr}$ is the leading factor; its content is high in all stainless grades throughout the process stages. The comparison of unit prices of valuable elements $(€ / \mathrm{kg})$ gives an order: $\mathrm{Cr}<<\mathrm{Ni}<<\mathrm{Mo}<\mathrm{V}$. In special cases, when high $\mathrm{Ni}$ or Mo steels are produced, their value in the steel and in metallic inclusions in slag can be even higher than the value of $\mathrm{Cr}$, respectively. For an efficient recovery, it is important to keep each special type of slag as its own lot and not to mix and dilute the valuable element into the big bulk of slags. As to other minor but valuable elements, vanadium contents are typically max tenths of a percent, but its recovery can be worth an inquiry. The same concerns titanium although it is less expensive.

For more quantitative recovery a pyrometallurgical treatment is an option. It might be a separate "reduction furnace" in which valuable metals could be reduced from the slag to very low contents in a properly stirred reactor under highly reducing conditions, e.g., in the presence of a $\mathrm{Fe}-\mathrm{C}$ or $\mathrm{Fe}-\mathrm{C}$ $\mathrm{Cr}$ melt. Also, other reductants like $\mathrm{Si}$ and $\mathrm{Al}$ are possible [15-21]. Cr bound is most difficult to reduce in spinels like $\mathrm{MgCr}_{2} \mathrm{O}_{4}$. Liquid slag and high temperature $\geq 1873 \mathrm{~K}$ make beneficial conditions to achieve over $95 \% \mathrm{Cr}$ recovery. Any ready industrial applications are not on the record, but such approaches have been examined. Both electric furnaces with electrodes and induction furnaces are feasible reactors. The product is liquid $\mathrm{Fe}-\mathrm{C}-\mathrm{Cr}$ alloy containing also other valuable metals depending on the initial slag composition. When a pyrometallurgical slag treatment furnace can be installed on-site in the steel plant, direct charging of the liquid slags can be applied. Then a much faster process and significant energy saving are achieved. Also, the metallic product is possible to use in situ. Depending on the unit processes inside a steel plant integrate, it can be possible to combine slags from stainless steelmaking with other industrial byproducts like blast furnace slag, slag from $\mathrm{FeCr}$ process, mill scales, pickling sludges, etc. [21-25].

Also, hydrometallurgical treatments afford means for recovery of valuable metals from stainless steelmaking slags. In a European CHROMIC project (Efficient mineral processing and hydrometallurgical recovery of by-product metals from low-grade metal-containing secondary raw materials), a comprehensive characterization of slags and a survey of different potential methods for metals recovery were performed [13, 14, 25-28]. Extraction of $\mathrm{Cr}$ has been promoted, e.g., via mechanical or microwave activation, alkaline roasting/leaching, and acid leaching. Other metals like V, Mo and $\mathrm{Ni}$ are possible to leach and recover selectively $[25,29,30]$. 
On the other hand, leaching tests can be used to determine the stability/instability of metals like $\mathrm{Cr}$ and $\mathrm{V}$ in the slag's mineral structure [31]. As pointed out earlier, the risk of leachable $\mathrm{Cr}$ and its oxidation to $\mathrm{Cr}(\mathrm{VI})$ is a potential risk in landfilled slag as well as in certain applications like fertilizer and soil conditioner. Therefore, the "residual chromium" in the slag should be stabilized as strongly as possible. For that purpose, binding $\mathrm{Cr}$ in spinel structure is a firm solution [31-37]. Low basicity and high $\mathrm{Al}_{2} \mathrm{O}_{3}$ and $\mathrm{MgO}$ favor spinel formation. A "spinel factor" was developed to define the dependency:

Factor $\mathrm{sp}=0.2 \mathrm{MgO}+1.0 \mathrm{Al}_{2} \mathrm{O}_{3}+n \mathrm{FeO}_{x}-0.5 \mathrm{Cr}_{2} \mathrm{O}_{3}(\mathrm{wt} \%)$.

The coefficient $\mathrm{n}$ gets values from 1 to 4 depending on the oxidation state of iron $\left(\mathrm{FeO}_{\mathrm{x}} \rightarrow \mathrm{Fe}_{2} \mathrm{O}_{3}\right)$. A strong spinel formation is attained with factor $\mathrm{sp}>5$ [32-35].

\section{Steering Slags Properties for Applications}

As described afore and presented in Table 1, several slags are generated in stainless steel smelting and refining and each slag type has its own chemical and mineralogical characteristics. They are mainly defined by the metallurgical demands of the targeted steel grade and eventual specific requirements (ferritic, austenitic, other high steel grades). The first one, i.e., EAF slag (black slag, EAFS) is mainly formed by calcium silicates, and it is rich in metallic oxides $\left(\mathrm{Cr}_{2} \mathrm{O}_{3}, \mathrm{FeO}, \mathrm{MnO}\right)$, in some cases up to $10 \%$ or even more. The minerals observed in the EAFS are $\beta$-Dicalcium-silicate $\left(\mathrm{Ca}_{2} \mathrm{SiO}_{4}\right)$, Bredigite $\left(\mathrm{Ca}_{1.7} \mathrm{Mg}_{0.3} \mathrm{SiO}_{4}\right)$, Merwinite $\left(\mathrm{Ca}_{3} \mathrm{MgSiO}_{8}\right)$, Melilite $\left(\mathrm{Ca}_{2} \mathrm{Al}_{2} \mathrm{SiO}_{7}-\mathrm{Ca}_{2} \mathrm{MgSi}_{2} \mathrm{O}_{7}\right)$, and Spinels $((\mathrm{Fe}, \mathrm{Mg})$ $\left.(\mathrm{Cr}, \mathrm{Fe})_{2} \mathrm{O}_{4}\right)$. This slag is compact and has a good volume stability. Characteristic to these slags is a wide composition variety owing to the batch process and heterogeneity of charge materials.

In the AOD process, the primary decarburization slag is reduced and adjusted to higher basicity for desulfurization and after this treatment tapped into a slag pot (single slag practice). In the case of demanding final sulfur target, the reduction slag can be tapped and an additional slag with higher basicity can be formed (2-slag practice). AOD reduction slag (AODS) is typically more basic than the EAFS and has a white color due to its low $\mathrm{Fe}, \mathrm{Mn}$, and $\mathrm{Cr}$ oxides. Mineral composition is not very divergent from EAFS consisting of calcium silicates and occasionally free lime $\left(\mathrm{CaO}_{\text {free }}\right)$ and cuspidine $\left(\mathrm{Ca}_{4} \mathrm{~F}_{2} \mathrm{Si}_{2} \mathrm{O}_{7}\right)$ originating from fluorspar additions for slag's fluxing, and no spinels. It is collected in slag pots in which also the desulfurization slag is poured in the case of 2-slag practice. AODS is composed mainly by crystals of $\beta$ - and $\gamma$-dicalcium silicate $\left(\mathrm{Ca}_{2} \mathrm{SiO}_{4}\right)$. These slags tend to disintegrate by the phase transition from $\beta$ - to $\gamma$-dicalcium silicate during cooling, causing dust generation. Another instability problem comes from hydration of free lime $\left(\mathrm{CaO}_{\text {free }}\right)$ and periclase $\left(\mathrm{MgO}_{\text {free }}\right)$ which are typically present in basic slags (AODS, LFS). Conventional "hot modification" of slag can be performed during slag tapping/pouring or in the slag pot by adding a "stabilizer" (borate, $\mathrm{MgO}, \mathrm{Al}_{2} \mathrm{O}_{3}$ ) which prevents the dust-forming $\beta-\mathrm{C}_{2} \mathrm{~S}$ to $\gamma-\mathrm{C}_{2} \mathrm{~S}$ transition [36-41].

A portion of the AODS slag is accompanying steel to the Ladle furnace where slag's composition is further adjusted by suitable additions $\left(\mathrm{CaO}, \mathrm{MgO}, \mathrm{CaF}_{2}, \mathrm{Ca}\right.$-aluminate slag) depending on the steel grade. The main functions and requirements of the ladle furnace slag (LFS) are to protect steel from contamination with air, to minimize heat losses, to improve cleanliness by absorbing inclusions from steel, and to minimize the wear of refractory lining [42]. This slag has a similar elemental and mineral composition as that one coming from AOD desulfurization, and thus, it is practical to incorporate them together. After all, in the stainless steel production, two basic types of slag can be distinguished: black EAFS with higher contents of metallic oxides and low basicity $(\mathrm{C} / \mathrm{S} \approx 1.5)$, and white slags from AOD, VOD, and LF, which are more basic $(\mathrm{C} / \mathrm{S} \geq 2.0)$ and with lower contents of metallic oxides.

\section{Effects and Potential Applications of Controlled Cooling}

Apart from slag chemistry, cooling rate is another way to control the mineralogical structure of the solidified slag. Slag's "journey" from the process conditions $\geq 1600{ }^{\circ} \mathrm{C}$ to outdoors temperature is, thus, extremely crucial, and it is strongly connected to utilization of slags in different applications. For different controlled cooling rates, several methods are available from slower to faster cooling: free air cooling in slag pot or bed $<$ the same with water spraying $<$ air granulation $<$ water quenching $<$ pouring thin layer on metal substrate or corresponding rapid cooling technique [43-50]. Rapid cooling can prevent crystallization in accordance with the phase diagram resulting in an amorphous glassy structure, encapsulating eventual metal particulates and solid oxides, and thereby lowering the solubility of heavy metals. Such a slag can be used for road construction. The tendency for glass formation is characteristic for acid viscous silicate slags and, thus, depends on both the chemical composition and the cooling conditions. Glasses, such as granulated slags, can be regarded as supercooled liquids with very high viscosity. By enhancing the fraction of amorphous material in a slag, the potential hydrating properties are improved, and the slag can be used in cement and concrete products for high-quality construction applications. Controlled cooling 
conditions can be a means to affect minerals formation and transformation and, consequently, the solubility of elements such as $\mathrm{Cr}$, Mo, and V. Their leachability depends on the distribution between glassy and crystalline phases which is influenced by the whole cooling curve including the hightemperature liquid and liquid-solid stages too [48-50].

Controlled slag cooling process gives a good opportunity for heat recovery as hot air or steam [51-57]. When producing amorphous slag as a substitute to cement dry granulation by air is the best choice. Such methods like rotary drum, spinning disks, and rotary cups are potential methods, offering the advantage of generating uniform and small grains at a lower energy consumption rate [52]. Better heat exchange is attained with smaller droplets resulting in better heat recovery and higher temperature, and the slag is quenched faster with less coolant. A two-step heat recovery system consisting of a fluidized bed, followed by a packed bed has been proposed to get maximal energy recovery efficiency, as both high outlet gas temperature and low slag discharge temperature are achieved [52]. In this form, the heat recovery is, however, only for energy storage before its final utilization. Better total energy efficiency could be achieved via chemical energy recovery methods which afford high energy density and zero loss when applied on-site without any transportation. Examples of processes under investigation are methane reforming and coal gasification $[55,56]$. Hydrogen production by decomposition of $\mathrm{CO}_{2}-\mathrm{CH}_{4}$ over hot-granulated slag in a packed bed has been studied. The slag acted not only as thermal media but also as a catalyst promoting the decomposition process $[58,59]$. Thermoelectric power generation appears to be an emerging technology in the future with many applications. Combined with an appropriate phase change material (PCM) as energy storage to solve the current mismatch between the high slag temperature and much lower operating range of thermoelectric materials, this technology might suit to the recovery of slag waste heat energy as well $[52,60]$.

\section{Current and Novel Slag Products and Applications}

In general, several steel slags have beneficial properties such as good strength, durability, and latent pozzolanic (cementitious) properties that make them attractive and potentially suitable for engineering applications, such as infrastructure construction, soil stabilization, neutralizer, as filler or binder in concrete or as drainage or low-permeability barrier layers [61-67]. Slags from stainless steelmaking are potential as well provided that the best suitable slag type is selected and modified by appropriate additions, cooling method, or other pre-treatments, i.e., tailoring for each specific application. Electric arc furnace slags (EAFS) have physical properties comparable to natural aggregates such as granite, e.g., high compressive strength and resistance to abrasion and, thus, fitted as landfill construction material. More basic slags (AODS, LFS) are potential substitutes as cementitious binders, thus, cutting $\mathrm{CO}_{2}$ emissions of the cement production [64-69]. Alkali activation is used to improve cementitious properties and to form hardening matrix, geopolymer [69, 70].

Different product applications of metallurgical slags in general and potential for stainless steel slags are collected in Fig. 3 by completing the previous process scheme. An essential stage is slags' treatment, which can be specific for each slag type and dependent on the target product. Recovery of metals and direct return to the in-plant processes or eventual external use are performed in this stage. Internal recycling of slag is possible as well, e.g., a part of AODS/ LFS could be returned to EAF as a $\mathrm{CaO}+\mathrm{MgO}$ source and slag forming agent. Thereafter, the slag lots continue to their final purposes, products, and uses. Some of these were
Fig. 3 The scheme of different unit processes in stainless steelmaking, slags formation, treatment, and product applications

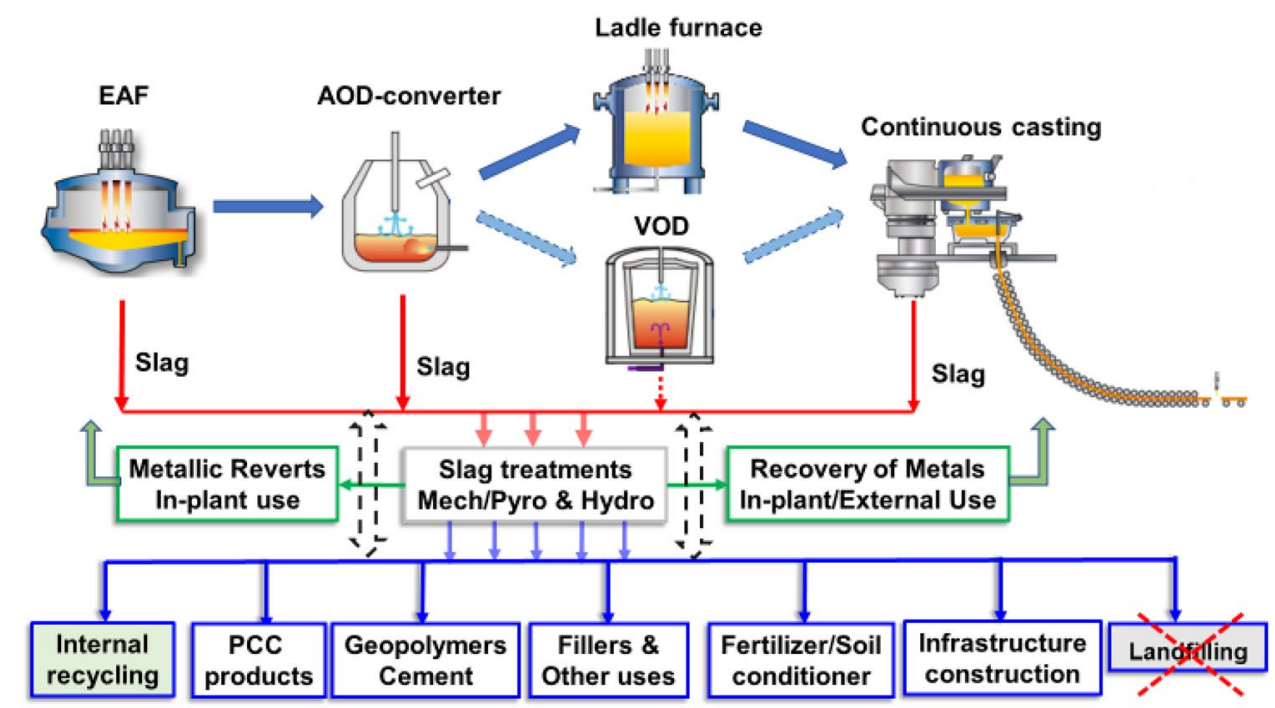


already discussed above. The use in fillers for instance as an ingredient in asphalt concrete has been studied [71, 72]. Precipitated calcium carbonate (PCC) is a relatively valuable product as a filler and pigment for paper industry. The conversion of slag to $\mathrm{PCC}$ means carbonization of $\mathrm{CaO}(\mathrm{MgO})$ in the slag to form $\mathrm{CaCO}_{3}$. Such decarbonization processes have been intensively studied; few examples are in references [73-77]. As a measure to mitigate $\mathrm{CO}_{2}$ emissions, it was estimated that utilization of one ton of EAFS for carbon capture could mineralize 0.38 tons of $\mathrm{CO}_{2}$ in the flue gas, via an accelerated carbonation process. The carbonated EAFS product could be used in cement mortar, with additional benefits. The whole global $\mathrm{CO}_{2}$ reduction potential by applying mineralization for iron and steelmaking slags was approxi-

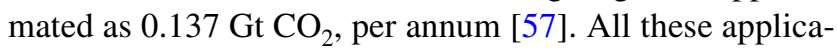
tions are substitutes for virgin materials and thus save natural resources and reduce $\mathrm{CO}_{2}$ emissions. Two dashed arrows between the "slag line" and "product line" describe the interactive relation slag's steering/treatment $\leftrightarrow$ application/ product. By integrating the treatments of slags and steering of their properties to the total process optimization system, the targets of circular economy could be attained, and the portion of landfilling minimized and even reset to zero.

\section{Economic Viewpoint}

The foregoing survey mainly started from environmental and metallurgical standpoints. For more advanced development and industrial exploitation, there must also be an explicit economic incentive. Figure 4 strives to outline the economic driver for slags treatment and productization. In the current situation, when most of stainless slags are landfilled, it means expenses (from tens to few hundreds $€ / t$ depending on the disposal tax and handling costs.

Anyway, the value is negative: large amounts and high total cost. By refining waste to resource and final useful products, the value turn to positive to tens/hundreds/thousands $€ / t$. The highest value Ca-based products might be
Fig. 4 Schematic illustration of the economic driver for slags' productization and reclaiming in high-value applications. The relative amounts of different products were approximated by the width of each box
Fig. 5 Estimated relative values of cash flow for different slag products (columns) and respective segments of slags (symbols blue square, red triangle) (Color figure online)
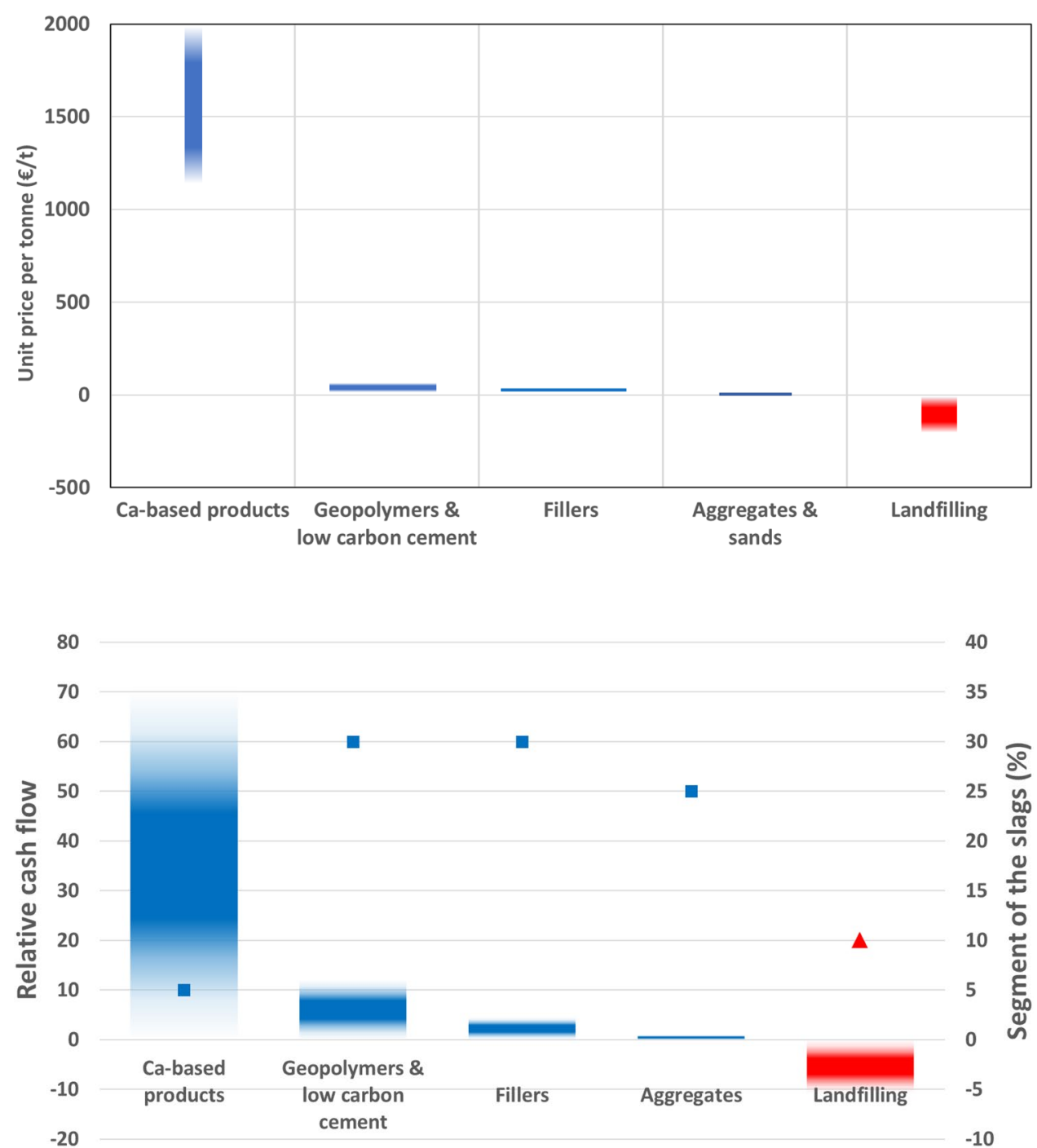
such products like food additives. Along with the valueadded production, the treatment expenses tend to grow and the quantities to decrease. As an offshoot of a large integrate, it can utilize the ready infrastructure which means low investment costs and raises its attractiveness. In Fig. 4, the conceivable volumes are presented by the width of each box. The fraction of "Landfilling" corresponds to the remaining landfilled amount after full productization.

Another economic approach is presented in Fig. 5 in which the cash flow of each slag product group was estimated. The cash flow values were calculated based on the approximated fraction of each product (as well as of landfilled slag) and its market price. It is seen that high-value Ca-based products with a volume of $5 \%$ might yield of the order of $2 / 3$ of the total cash flow. For the total economic value estimation also, the production costs should be approximated, respectively.

\section{Concluding Remarks}

The world of stainless steel production is strongly growing. As a consequence, the amount of produced slags increase rapidly. Today, most of these slags go to landfilling, although there are varying practices in different companies. The utilization degree has been low due to their small amounts and complexity. Slags landfilling can cause environmental and health risks due to metal and fluoride contents. Tightening environmental requirements and demands for circularity are pressing for reassessment and corrective actions. On the positive side, the slags have a great economic, technical, and ecologic potential, when properly recycled, recovered, and productized. The main results of the survey can be condensed into a few remarks.

1. Optimized running of the unit processes (EAF-AOD/ VOD-LF-CC) is a central issue considering slags' properties as for the function of the slag in the primary process and for the subsequent slag processing for specific products.

2. For the steelmaking process, it is crucial to minimize metal losses into the process slags, and to obtain efficient metals recovery from the slags.

3. As the slags, however, always contain valuable alloying metals $(\mathrm{Cr}, \mathrm{Ni}, \mathrm{Mo})$, their efficient recovery is a key economic issue. Also, minor elements (V, Ti) should be considered. In addition to mechanical separation, chemical treatments, leaching, and extraction are attractive. Via selective individual processing of different slag types, the recovery of metals could be maximized.

4. The composition and mineralogical structure of the slags can be steered by modifying additions and controlled cooling. Heat recovery from molten slag is a potential option too.

5. Slag granulation equipped with heat recovery as hot air could produce significant amounts of high-quality material to construction purposes with minimal energy and low carbon footprint.

6. High total energy efficiency could be achieved via chemical energy recovery methods for production of synthesis gas, hydrogen, or even direct conversion to electricity. Such techniques are under development.

7. Concerning slags, utilization and productization, stainless steel slags are suitable to special high-value products due to relatively small quantities with well-specified chemistry and properties. An economic assessment was performed exhibiting the potential to minimize landfilling costs and turn to positive cash flow by developing a group of low and medium to high-value products. Precipitated Calcium Carbonate PCC is an example of a valuable product for paper industry. As a bonus, it binds $\mathrm{CO}_{2}$ and mitigates the carbon footprint of steel production.

8. Furthermore, on a wider scope, slags' comprehensive utilization results in significant energy saving and direct and indirect reduction of $\mathrm{CO}_{2}$ emissions. These issues, as well as the elimination of environmental and health risks, can be summarized by the phrase "turning threats into opportunities."

Acknowledgements This article is based on the presentation at the 11th International Conference on Molten Slags, Fluxes and Salts, Feb 21-25, 2021, Korea. The authors are truly grateful to Professor Dong Yoon Min and Joohyun Park and the Conference Team for organizing this excellent MOLTEN 2021 Virtual Conference and for all your kindness and efforts to its success. Thanks to the Association of Finnish Steel and Metal Producers' Fund for the financial support (LH).

Funding Open access funding provided by Aalto University.

\section{Declarations}

Conflict of interest The authors declared that they have no conflict of interest.

Open Access This article is licensed under a Creative Commons Attribution 4.0 International License, which permits use, sharing, adaptation, distribution and reproduction in any medium or format, as long as you give appropriate credit to the original author(s) and the source, provide a link to the Creative Commons licence, and indicate if changes were made. The images or other third party material in this article are included in the article's Creative Commons licence, unless indicated otherwise in a credit line to the material. If material is not included in the article's Creative Commons licence and your intended use is not permitted by statutory regulation or exceeds the permitted use, you will need to obtain permission directly from the copyright holder. To view a copy of this licence, visit http://creativecommons.org/licenses/by/4.0/. 


\section{References}

1. ISSF: Stainless Steel in Figures (2020) https://www.worldstain less.org/Files/issf/non-image-files/PDF/ISSF_Stainless_Steel_in_ Figures_2020_English_public_version.pdf. Accessed 3 Feb 2021

2. World Steel Association (2020) World steel in figures. https:// www.worldsteel.org/en/dam/jcr:f7982217-cfde-4fdc-8ba0-795ed 807f513/World\%2520Steel\%2520in\%2520Figures\%25202020i. pdf. Accessed 3 Feb 2020

3. Horckmans L, Nielsen MRP, Kukurugya F, Vanhoof C, Morillon A, Algermissen D (2019) Multi-analytical characterization of slags to determine the chromium concentration for a possible reextraction. Minerals 9:1-14. https://doi.org/10.3390/min9100646

4. Ma G, Garbers-Craig AM (2006) Cr(VI) containing electric furnace dusts and filter cake from a stainless steel waste treatment plant: part 1-characteristics and microstructure. Ironmak Steelmak 33(3):229-237

5. Ma G, Garbers-Craig AM (2006) $\mathrm{Cr}(\mathrm{VI})$ containing electric furnace dusts and filter cake from a stainless steel waste treatment plant: part 2-formation mechanisms and leachability. Ironmak Steelmak 33(3):238-244

6. Guo M, Durinck D, Jones PT, Heylen G, Hendrickx R, Baeten R, Blanpain B, Wollants P (2007) EAF stainless steel refining-part I: observational study on chromium recovery in an eccentric bottom tapping furnace and a spout tapping furnace. Steel Res Int 78:117-124.

7. Durinck D, Jones PT, Guo M, Verhaeghe F, Heylen G, Hendrickx R, Baeten R, Blanpain B, Wollants P (2007) EAF stainless steel refining part II: microstructural slag evolution and its implications for slag foaming and chromium recovery. Steel Res Int 78(2):125-135

8. Xiao Y, Holappa L, Reuter MA (2002) Oxidation state and activities of chromium oxides in $\mathrm{CaO}-\mathrm{SiO}_{2}-\mathrm{CrO}_{\mathrm{x}}$ slag system. Metall Mater Trans B 33B:595-603

9. Holappa L, Forsbacka L (2008) Chromium in slags. In: Proc. SANO Symposium, ISIJ 2-3 Oct. 2008, Tokyo, pp 11.

10. Mehlman SK (1991) Pneumatic steelmaking: The AOD process. Iron and Steel Society, Warrendale

11. Guthrie RIL, Isac M, Lin Z-H (2005) Fluid dynamics simulation of chromium recovery from AOD slags during reduction with ferrosilicon additions. Ironmak Steelmak 32(2):133-140

12. Visuri VV (2017) Mathematical modelling of chemical kinetics and rate phenomena in the AOD Process. University of Oulu Graduate School; Faculty of Technology, Acta Univ. Ouluensis. C 625, pp 290. http://jultika.oulu.fi/files/isbn9789526216713.pdf

13. Wang X, Geysen D, Van Gerven T, Jones PT, Blanpain B, Guo M (2017) Characterization of landfilled stainless steel slags in view of metal recovery. Front Chem Sci Eng 11(3):353-362

14. Kukurugya F, Horckmans L, Spooren J (2019) Recovering chromium from stainless steel and ferrochrome slags, 6th international slag valorisation symposium. Mechelen 04:201-204

15. Sano N (2004) Reduction of chromium oxide in stainless steel slags. In Proceedings of 10th international ferroalloys congress. South African Institute of Mining and Metallurgy, Cape Town. pp 670-677.

16. Leuchtenmüller M, Antrekowitsch J, Steinlechner S (2019) A kinetic study investigating the carbo-thermic recovery of chromium from a stainless-steel slag. Metall Mater Trans B 5:2221-2228

17. Ji Y, Shen S, Liu J, Yan S, Zhang Z, Xue Y (2017) Steel Res Int 88(9):1-8

18. Nakasuga T, Nakashima K, Mori K (2004) Recovery rate of chromium from stainless slag by iron melts. ISIJ Int 44(4):665-672
19. Adamczyk B, Brenneis R, Adam C, Mudersbach D (2010) Recovery of chromium from AOD-converter slags. Steel Res Int 81(12):1078-1083

20. Ji FZ, Barati M, Coley K, Irons AG (2004) A kinetic study of carbon injection into electric arc furnace slags. In Proceedings of VII international conference on molten slags fluxes and salts (SAIMM), pp 399-405.

21. Outokumpu (2019) https://www.outokumpu.com/en/news/2019/ outokumpu-assesses-options-to-build-a-new-slag-furnace-in-torni o,-finland. Accessed 29 Nov 2019

22. Yang CC, Pan J, Zhu DQ, Guo ZQ, Li XM (2019) Pyrometallurgical recycling of stainless steel pickling sludge: a review. J Iron Steel Res Int 26:547-557

23. Li XM, Mousa E, Zhao JX, Cui YR (2009) Recycling of sludge generated from stainless steel pickling process. In Proceedings of the 5th international congress science and technology of ironmaking, Shanghai, pp483-87.

24. Heikkinen EP, Leinonen V, Tanskanen P, Fabritius T (2017) A computational study to estimate the possibilities to improve utilisation of stainless steelmaking slags. In Proceedings of 1st international conference energy and material efficiency and $\mathrm{CO}_{2}$ reduction in the steel industry( EMECR). Kobe, Japan 11-13 Nov. 2017, pp 86-89.

25. Horckmans L, Spooren J, Kukurugya F (2017) Euroslag 2017, CHROMIC: new processes to recover metals from carbon steel, stainless steel and ferrochrome slags. http://www.chromic.eu/wpcontent/uploads/2017/10/4-4_Horckmans.pdf. Accessed 29 Dec 2020.

26. Pikna L, Hezelova M, Morillon A, Algermissen D, Milkovic O, Findorak R, Cesnek M, Briancin J (2020) Recovery of chromium from slags leachates by electrocoagulation and solid product characterization. Metals 10:1593. https://doi.org/10.3390/met10 121593

27. Kim E, Spooren J, Broos K, Horckmans L, Quaghebeur M, Vrancken KC (2015) Selective recovery of Cr from stainless steel slag by alkaline roasting followed by water leaching. Hydrometallurgy 158:139-148

28. Kim E, Spooren J, Broos K, Nielsen P, Horckmans L, Vrancken KC, Quaghebeur M (2016) New method for selective Cr recovery from stainless steel slag by $\mathrm{NaOCl}$ assisted alkaline leaching and consecutive $\mathrm{BaCrO}_{4}$ precipitation. Chem Eng J 295:542-551

29. Spooren J, Kim E, Horckmans L, Broos K, Nielsen P, Quaghebeur M (2016) In-situ chromium and vanadium recovery of landfilled ferrochromium and stainless steel slags. Chem Eng J 303:359-368

30. Ye G, Burström E, Kuhn M, Piret J (2003) Reduction of steelmaking slags for recovery of valuable metals and oxide materials. Scand J Metall 32:7-14

31. Neuhold S, Van Zomeren A, Dijkstra JJ, Van der Sloot HA, Drissen P, Algermissen D, Mudersbach D, Schüler S, Griessacher T, Raith JG, Pomberger R, Vollprecht D (2019) Investigation of possible leaching control mechanisms for chromium and vanadium in electric arc furnace (EAF) slags using combined experimental and modeling approaches. Minerals 9:525. https://doi.org/10. 3390/min9090525

32. Kühn M, Mudersbach D (2004) Treatment of liquid EAF-slag from stainless steelmaking to produce environmental friendly construction materials. In Proc. of the SCANMET II-2nd international conference on process development in iron and steelmaking, Lulea, Sweden, 6-9 June 2004, pp 369-377.

33. Mudersbach D, Kühn M, Geisler J, Koch K (2009) Chrome immobilisation in EAF-slags from high alloy steelmaking: tests at FEhS institute and development of an operational slag treatment process. In Proceedings of 1st international slag valorisation symposium, Leuven, Belgium, pp 101-110. 
34. Albertsson G (2013) Abatement of chromium emissions from steelmaking slags-Cr stabilization by phase separation. ISBN 978-91-7501-666-5, pp 62.

35. Engström F (2010) Mineralogical influence on leaching behaviour of steelmaking slags, Doctoral Thesis, Luleå University of Technology, LTU, Sweden, pp 210.

36. Shen H, Forssberg E, Nordström U (2004) Physicochemical and mineralogical properties of stainless steel slags oriented to metal recovery. Resour Conserv Recycl 40:245-271

37. Zhao Q, Liu C, Cao L, Zheng X, Jiang M (2018) Effect of lime on stability of chromium in stainless steel slag. Minerals 8:424. https://doi.org/10.3390/min8100424,pp.10

38. Durinck D, Jones PT, Arnout S, Blanpain B (2009) Stainless steel slag valorisation: on volume stability and disintegration. In Proc. 1st international slag valorisation symposium, Leuven 6-7/4/2009, pp. 81-91

39. Iacobescu RI, Malfliet A, Machiels L, Jones PT, Blanpain B, Pontikes Y (2014) Stabilisation and microstructural modification of stainless steel converter slag by addition of an alumina rich byproduct. Wast Biomass Valoriz 5:343-353

40. Greenhill-Hooper M, Schubert DM, Wilhelm T (2007) Upgrading stainless steel slags with borate. In Iron and Steel Technology, January 2007 PR-351-094 -2007, p 8.

41. Brand AS, Fanijo EO (2020) A review of the influence of steel furnace slag type on the properties of cementitious composites. Appl Sci 10:8210. https://doi.org/10.3390/app1022821,pp.27

42. Pretorius EB, Nunnington RC (2002) Stainless steel slag fundamentals - from furnace to tundish. Ironmak Steelmak 29(2):133-139

43. Kriskova L (2013) Breakthrough applications for stainless steel slags-development of novel application for AOD and LM slags. Dr Eng Thesis, May 2013, Katholieke Univ. Leuven, Groep Wetenschap \& Technologie, Arenberg Doctoraatsschool, W. de Croylaan 6, 3001 Heverlee, België. pp 179.

44. Zhao Q, Liu C, Cao L, Zheng X, Jiang M (2018) Stability of chromium in stainless steel slag during cooling. Minerals 8(10):445

45. Loncnar M, Mladenovič A, Zupančič M, Bukovec P (2017) Comparison of the mineralogy and microstructure of EAF stainless steel slags with reference to the cooling treatment. J Mining Metall Sect B 53(1):19-29. https://doi.org/10.2298/JMMB150910 $018 \mathrm{~L}$

46. Kärnä A, Sulasalmi P, Visuri VV, Heikkinen EP, Fabritius T, Torvinen P, Koskinen J (2019) Numerical modelling of slag cooling. In Proceedings of the 4th European steel technology and application days, June 2019, VDEh Düsseldorf, Germany, pp 5.

47. Kriskova L, Pontikes Y, Pandelaers L, Cizer O, Jones PT, Van Balen K, Blanpain B (2013) Effect of high cooling rates on the mineralogy and hydraulic properties of stainless steel slags. Metall Mater Trans B 44B:1173-1184

48. Zeng Q, Li J, Yu Y, Zhu H (2020) Effect of cooling rate on crystallization behaviour of $\mathrm{CaO}-\mathrm{SiO}_{2}-\mathrm{MgO}-\mathrm{Cr}_{2} \mathrm{O}_{3}$ based slag. High Temp Mater Proc 39:74-80. https://doi.org/10.1515/ htmp-2020-0023

49. Li GJ, Ni HW (2011) Recent progress of hot stage processing for steelmaking slags in China considering stability and heat recovery. In 2nd international slag valorisation symposium, Leuven, Belgium, 18-20 April 2011, pp 253-261

50. Manchisi J, Matinde E, Rowson NA, Simmons MJH, Simate GS, Ndlovu S, Mwewa B (2020) Ironmaking and steelmaking slags as sustainable adsorbents for industrial effluents and wastewater treatment: a critical review of properties, performance, challenges and opportunities. Sustainability 12(2118):47. https://doi.org/10. 3390/su12052118

51. Bisio G (1997) Energy recovery from molten slag and exploitation of the recovered energy. Energy 22(5):501-509
52. Barati M, Esfahani S, Utigard TA (2011) Energy recovery from high temperature slags. Energy 36(9):5440-5449

53. Zhang H, Wang H, Zhu X, Qiu Y-J, Li K, Chen R, Liao Q (2013) A review of waste heat recovery technologies towards molten slag in steel industry. Appl Energy 112:956-966

54. Barati M, Jahanshahi S (2020) (2020); Granulation and heat recovery from metallurgical slags. J Sustain Metall 6:191-206. https:// doi.org/10.1007/s40831-019-00256-4

55. Sun Y, Zhang Z, Liu L, Wang X (2015) Heat recovery from high temperature slags: a review of chemical methods. Energies 8:1917-1935. https://doi.org/10.3390/en8031917

56. Sun Y, Zhang Z (2016) Heat recovery from high temperature slags: chemical methods. In: Li L et al (eds) Energy technology 2016. Springer, Cham

57. Shu C, Pan Y, Chung T-C, Ho C-C, Hou C-J, Chen Y-H, Chiang $\mathrm{P}-\mathrm{C}$ (2017) $\mathrm{CO}_{2}$ mineralization and utilization using steel slag for establishing a waste-to-resource supply. Sci Rep 7:17227

58. Purwanto H, Akiyama T (2006) (2006); Hydrogen production from biogas using hot slag. Int J Hydrogen Energy 31(31):491495. https://doi.org/10.1016/j.ijhydene.2005.04.021

59. Sun Y, Chen J, Zhang Z (2018) Biomass gasification using the waste heat from high temperature slags in a mixture of $\mathrm{CO}_{2}$ and $\mathrm{H}_{2} \mathrm{O}$. Energy. https://doi.org/10.1016/j.energy.2018.11.019

60. Okinaka N, Nomura T, Akiyama T (2010) Technology of latent heat storage for high temperature application: a review. ISIJ Int 50(9):1229-1239

61. Tossavainen $\mathrm{M}$ (2005) Leaching results in the assessment of slag and rock materials as construction material. PhD Thesis, Luleå University, 44:160. DiVA, id: diva2:991617

62. Salman M, Dubois M, Di Maria A, Van Acker K, Van Balen K (2016) Construction materials from stainless steel slags: technical aspects, environmental benefits, and economic opportunities. J Ind Ecol 4:854-866

63. De Colle M, Jönsson P, Karasev A, Gauffin A, Renman A, Renman $G$ (2019) The use of high-alloyed EAF slag for the neutralization of on-site produced acidic wastewater: the first step towards a zero-waste stainless steel production process. Appl Sci 9:3974. https://doi.org/10.3390/app9193974

64. Kriskova L, Eroli M, Iacobescu RI, Onisei S, Vecchiocattivi F, Pontikes Y (2018) (2017) Transformation of stainless steel slag toward a reactive cementitious binder. J Am Ceram Soc 101:1727-1736. https://doi.org/10.1111/jace.15306

65. Sheen Y-N, Wang H-Y, Sun T-H (2013) A study of engineering properties of cement mortar with stainless steel oxidizing slag and reducing slag resource materials. Constr Build Mater 40:239-245

66. Sheen Y-N, Le D-H, Sun T-H (2015) Innovative usages of stainless steel slags in developing self-compacting concrete. Constr Build Mater 101:268-276

67. Cheng S, Shui Z, Yu R, Zhang X, Zhu S (2018) Durability and environment evaluation of an eco-friendly cement-based material incorporating recycled chromium containing slag. J Clean Prod $185: 23-31$

68. Nguyen H, Kinnunen P, Gijbels K, Carvelli V, Sreenivasan H, Kantola AM, Telkki V-V, Schroeyers W, Illikainen M (2019) Ettringite-based binder from ladle slag and gypsum-the effect of citric acid on fresh and hardened state properties. Cement Concrete Res 123:12

69. Bishow KC, Gautam BST (2019) Utilization of steel slag as a replacement for filler material in the asphalt concrete. In Proc. IOE Graduate Conference, 2019-Winter, vol 7, pp 235-241

70. Adesanya E, Ohenoja K, Kinnunen P, Illikainen M (2017) Alkali activation of ladle slag from steel-making process. J Sustain Metall 3:300-310. https://doi.org/10.1007/s40831-016-0089-x

71. Lancellotti I, Piccolo F, Traven K, Cešnovar M, Ducman V, Leonelli C (2021) Alkali activation of metallurgical slags: reactivity, 
chemical behavior, and environmental assessment. Materials 14(639):19. https://doi.org/10.3390/ma14030639

72. Garcia JR, Agrela F, Entrenas JA, Cabrera M (2020) Potential of stainless steel slag waste in manufacturing self-compacting concrete. Materials 13(9):17. https://doi.org/10.3390/ma13092049

73. Zhao Q, Liu K, Sun L, Liu C, Jiang M, Saxén H, Zevenhoven R (2020) Towards carbon sequestration using stainless steel slag via phase modification and co-extraction of calcium and magnesium. Process Saf Environ Prot 133:73-81. https://doi.org/10.1016/j. psep.2019.11.004

74. Santos RM, Van Bouwel J, Vandevelde E, Mertens G, Elsen J, Van Gerven T (2013) Accelerated mineral carbonation of stainless steel slags for $\mathrm{CO}_{2}$ storage and waste valorization: effect of process parameters on geochemical properties. Int J Greenhouse Gas Control 17:32-45
75. Humbert PS, Castro-Gomes J (2019) $\mathrm{CO}_{2}$ activated steel slagbased materials: a review. J Clean Prod 208:448-457

76. Salman M, Cizer Ö, Pontikes Y, Santos RM, Snellings R, Vandewalle L, Blanpain B, Van Balen K (2014) $\mathrm{CO}_{2}$ activated steel slag-based materials: a review. Chem Eng J 246:39-52

77. Santos RM, François D, Mertens G, Elsen J, Van Gerven T (2013) Ultrasound-intensified mineral carbonation. Appl Therm Eng $57: 154-163$

Publisher's Note Springer Nature remains neutral with regard to jurisdictional claims in published maps and institutional affiliations. 